\title{
SAMA grasps the racial nettle, winning huge majority vote
}

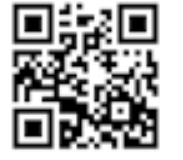

An internal wrangle over how all racial groups are fairly represented in the South African Medical Association (SAMA) led to all-time record attendance at an Extraordinary General Meeting in Pretoria last month, where an $89 \%$ majority backed a pragmatic redefinition of non-racialism.

The catalyst for the unusual gathering was vociferous objections by a minority of members of the former 'Partner Organisations' (POs) after the current SAMA President, Prof. Ames Dhai, changed the wording of the 2013 Memorandum of Incorporation (MOI). This MOI reflected the historic 1997 Agreement of Understanding (AOU) between the POs and the former predominantly white Medical Association of South Africa (MASA). With her Board's unanimous backing, on 21 February this year Dhai changed the words 'Founder Groups' (read Partner Organisations) to 'Historically Disadvantaged Individuals' (HDIs) in a paragraph which decrees that they have at least $50 \%$ representation. The Board asked her, through a unanimously approved resolution in December last year, to guide them and make a determination on the nonresolution of the MOI and Company Rules that they had been grappling with for some time. The POs were the Dispensing Family Practitioners Association, the Eastern Cape Medical Group, the South African Medical and Dental Practitioners, the Society for Dispensing Family Practitioners and the Progressive Doctors Group. The latter had dissolved soon after the AOU had been signed. A majority of Board members maintains that the original agreement was a transitional instrument to enable a more equitable, demographically evolving and representative organisation.

A group claiming to represent the POs, calling itself the National Medical Forum (NMF) and led by current SAMA Board member Dr Mohamed Adam, said Dhai's intervention legally and technically altered the bed-rock transformation of SAMA, labelling it a politically inspired conservative regression 'back to the apartheid MASA'. The NMF is demanding, on threat of legal action, that SAMA stick to the definition of the original POs when ensuring $50 \%$ representation in all SAMA

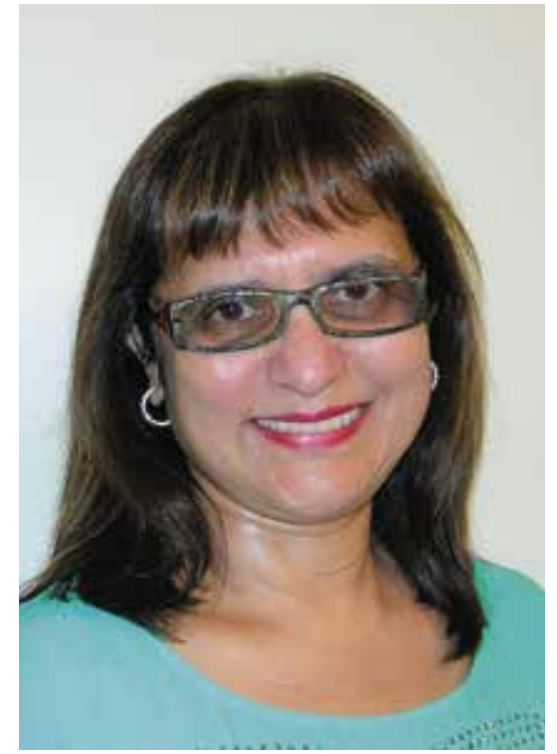

Prof. Ames Dhai, SAMA President.

structures. However, backed by her Board (and the subsequent $89 \%$ vote for the new MOI), Dhai says she cannot find proof that the various POs are still legally viable and functioning with constituent memberships and constitutions. She cited contacting one of the NMF's list of PO executive members, who told her that the last time members of that organisation had met was 10 years ago and that it was in actual fact, defunct'. Dhai, a leading bioethicist with a master's degree in law, said she found herself 'challenged with the ethics and morality of including shadow entities in the MOI, a founding document of the SAMA processes'. SAMA's dilemma was this: had it stuck to the atrophied original $\mathrm{MOI}$ and $\mathrm{AOU}$, the voting rights of branch and therefore Council members would be over-ridden by the $50 \%$ PO representivity clause, rendering powerless doctors who had long served their constituencies.

Said Dhai: 'It's very sad that you have a small group of individuals that, under the guise of transformation, want to autocratically rule the SAMA membership. We have a beautiful constitution in our country and we're 20 years into our democracy. SAMA has transitioned towards a pluralistic, multiracial and multicultural membership that is rich in its diversity and is well into the process of transformation, as evidenced by the trend in its demographic composition since 1998. Any revision of its MOI and Company Rules must be reflective and supportive of this growth.' The NMF's inflexible position ignored these positive shifts and would take SAMA back to its preconception phase, she added.

A sustained NMF internet and email campaign that questioned Dhai's competence and qualifications, queried SAMA Chairman Dr Mzukizi Grootboom's honesty and cast suspicion on his and his deputy Dr Mark Sonderup's motivation led to an all-time attendance record at the 12 April Extraordinary General Meeting in Pretoria - in terms of both proxy votes and physical presence of members. Grootboom rejected the disgraceful endeavour by a few individuals to win favour for their distorted objectives via smear campaigns in the social and online media, with the contempt it deserves'. He said the overwhelmingly supportive vote meant that SAMA could now confidently and unambiguously move forward to tackle the country's pressing social issues, knowing that all its structures reflected representation of HDIs by at least $50 \%$.

Asked by Izindaba about SAMA's current membership demographics, Dhai said estimates were ' $50 \%$ people of colour and $50 \%$ white. 'SAMA does not include race when capturing the demographic details of its members, so transformation status will be derived from surnames. This is not ideal and almost certainly under-represents

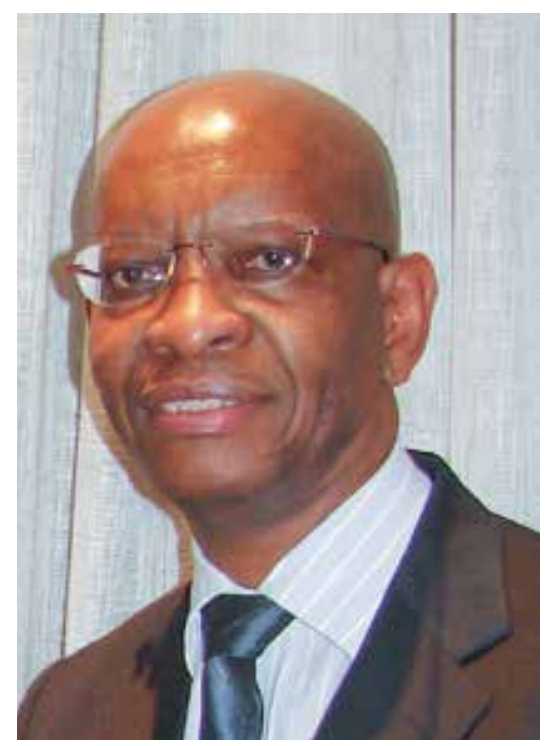

SAMA Chairman Dr Mzukisi Grootboom. 
people of colour in the Association, she added. She explained that the transition from apartheid in training doctors, regardless of colour, was a process. Medical schools in the country had not yet reached the stage at which graduating doctors were reflective of the country's current racial demographic profile.

The NMF accused Dhai of flouting her mandate and being legally unqualified, and described the Board resolution as 'a Trojan horse', passed under false pretenses. It alleged that Board members Drs Zameer Brey and Sonderup helped craft the "hastily worded' resolution, rendering it binding on the Board. The NMF said the 'new model' effectively disempowered the five predominantly black organisations that helped give birth to SAMA and called it ' $u$ ltra vires and unlawful', threatening to hold the relevant Board members personally liable. Dhai denied all allegations, adding that Dr Adam was present at the Board meeting and that he also voted for the resolution, which was approved unanimously.

Prof. Denise White, vice-chair and interim chair of SAMA during some of its most turbulent years $(2002-2009)$ and herself a former target of a social media vilification campaign, said she was getting calls from confused and annoyed non-SAMA members asking how their emails were accessed by the NMF and what was going on, after reading the NMF's recent cyber campaign material. She said that even during her tenure, extracting membership lists from the POs was a recurring problem - which begged the question of whether the POs were being leveraged for personal agendas. 'Even in those days, they didn't have the transparency to come up with a list of, say, 100 people, she said. White said that, ironically, SAMA's current leadership was 'totally transformed, demographically', while the executives of the junior doctors' and registrars' associations were 'more than' demographically repre- sentative. The cyber-smear campaign had 'clearly backfired', frustrating members who wanted the organisation to focus on more urgent healthcare delivery and professional issues.

An elective SAMA National Council meeting was held on 23/24 May (beyond the deadline of this article), at which the controversy was expected to be thoroughly aired and 'put to bed' to enable 'more pressing matters', including the Competitions Commission probe into the private healthcare industry, National Health Insurance implementation, the controversial 'Certificate of Need' and labour relations/trade union matters, to be engaged with as a matter of urgency.

\section{Chris Bateman}

chrisb@hmpg.co.za

S Afr Med J 2014;104(6):394-395.

DOI:10.7196/SAMJ.8436 